\title{
FAKTOR-FAKTOR PEMILIHAN LOKASI SHOPPING MALL DI KOTA SURAKARTA
}

\author{
Darryl Hall Stevanda Dwi Satria ${ }^{1}$, Winny Astuti ${ }^{1}$, Erma Fitria Rini ${ }^{1}$ \\ ${ }^{1}$ Program Studi Perencanaan Wilayah dan Kota Fakultas Teknik Universitas Sebelas Maret Surakarta
}

\begin{abstract}
Abstrak
Lokasi merupakan penentu daya tarik suatu pasar modern. Beberapa aktor yang menentukan lokasi optimum suatu retail/perdagangan yaitu aksesibilitas, specific site, kebijakan zonasi, kesesuaian aturan zonasi, aksesibilitas, harga tanah, ketersediaan jaringan prasarana, kesesuaian kondisi geologi dan hidrologi, jarak jangkauan customer, dan tenant mix. Shopping mall umumnya merupakan bangunan besar, tertutup lantai lebih dari satu dengan luas minimal $9200 \mathrm{~m}^{2}$ dengan karakteristik utama pusat perbelanjaan dalam satu atap atau one stop. Perkembangan penanaman modal di Surakarta sebagai Trade Centre membuat banyak investor yang menanamkan modalnya dibidang perdagangan, termasuk shopping mall. Perkembangan Shopping mall diawali pada tahun 2004 ketika Solo Grand Mall berdiri, selanjutnya Solo Square pada tahun 2006 dan Solo Paragon pada tahun 2010. Penelitian ini bertujuan untuk mengetahui faktor prioritas yang mempengaruhi pemilihan lokasi Shopping mall di Kota Surakarta. Metode yang digunakan adalah dengan menggunakan analisis prioritas dalam Analytic Hierarchi Process. Berdasarkan hasil analisis AHP, faktor yang menjadi prioritas bagi shopping mall di Kota Surakarta secara berurutan yaitu peraturan zonasi Daerah Setempat, Konsumen dan Ketersediaan Moda Transportasi, Tingkat Arus Lalu Lintas, Kemudahan Dicapai dari Fasilitas umum, ketersediaan jaringan listrik, biaya (harga lahan), ketersediaan jaringan drainase, kesesuaian kondisi geologi dan hidrologi, suspicient, generative, dan yang terakhir adalah lokasi dan jarak dengan pesaing.
\end{abstract}

Kata kunci : faktor pemilihan lokasi; shopping mall; AHP

\begin{abstract}
Location is an attractive determiner of a modern market. The factors determining optimum of a retail/commerce are the accessibility, the specific site, the zoning policy, the compatibility zoning regulation, the accessibility, the price of land, the availability of infrastructure system, the compatibility condition of geology and hydrology, the range of customer, and Tenant Mix. Generally, Shopping mall is a high building having more than one story with minimum wide of $9200 \mathrm{~m}^{2}$ with the main characteristic of one stop shopping center. The development of investment in Surakarta, as Trade Centre, has many people invested in commercial field, including Shopping mall. The development of Shopping mall started when Solo Grand Mall is built in 2004, then Solo Square in 2006 and Solo Paragon in 2010. They all have the same factor of choosing the location that is in the South part of Surakarta. This research is purposes to discover the priority factors affecting the choosing location of Shopping mall in Surakarta by using priority analysis in Analytic Hierarchi Process. In result, the priority factors are the regulation of zoning local, consumen and the availability of transportation, Traffic level, the convenient reach of public facility, the availability of electrical system, the price of land, the availability of drainage system, the compatibility condition of geology and hydrology, Suspicient, Generative, and the last but not least is the location and the distance with other Shopping mall.
\end{abstract}

Keywords : AHP; location decision factor; shopping mall

\section{PENDAHULUAN}

Lokasi merupakan penentu daya tarik suatu pasar modern. Faktor lokasi sangatlah penting baik bagi developer/investor sebagai pihak yang menentukan lokasi pasar modern, maupun tenant di dalamnya. Faktor- faktor yang mempengaruhi investor memilih lokasi pembangunan pasar modern adalah aksesibilitas, specific site, kebijakan zonasi (Berman \& Evan, 2001). Pertimbangan pemilihan lokasi pasar modern adalah konsumen, aksesibilitas, lokasi pesaing dan cost (Gilbert, 2003).

Dalam RUPM (Rencana Umum Penanaman Modal) Kota Surakarta pada tahap III (2020-2025) salah satu sasaran yang diambil adalah Kota Surakarta menjadi pusat perdagangan (Trade Center) dan penanaman modal akan dipusatkan 
pada investasi perdagangan dan jasa. Dengan adanya Rencana Umum Penanaman Modal di Kota Surakarta membuat para investor semakin tertarik dalam pengembangan pasar modern. Dalam berbagai jenis pasar modern yang ada, pasar modern yang berkembang di Kota Surakata adalah bangunan shopping mall. Shopping mall didefinisikan sebagai sebuah bangunan besar, bertingkat yang terdiri atas banyak outlet/tenant dengan luasan minimal 100.000 kaki persegi atau sekitar $9.200 \mathrm{~m} 2$ (Gilbert, 2003).

Terdapat tiga shopping mall yang berkembang di Kota Surakarta ini yaitu Solo Grand Mall, Solo Square dan Solo Paragon. Ketiga shopping mall yang telah ada di Kota Surakarta ini dibangun dilokasi yang berdekatan. Jarak antar shopping mall ini tidak lebih dari $2 \mathrm{~km}$ dan shopping mall ini mengelompok di bagian selatan Kota Surakarta. Disisi lain, pembangunan shopping mall di Surakarta bagian utara seakan kurang diminati oleh investor.

Terdapat kecenderungan ketiga shopping mall tersebut untuk mengelompok dengan memilih lokasi pada bagian selatan Kota Surakarta sehingga menimbulkan pertanyaan faktor apa saja yang mempengaruhi ketiga investor tersebut memilih lokasi pembangunan shopping mall yang saling berdekatan/tidak menyebar. Jika dilihat berdasarkan lokasinya, shopping mall di Kota Surakarta memiliki keterkaitan spasial satu sama lain dan mempengaruhi faktor pemilihan lokasi pembangunan tersebut. Oleh karena itu, faktor-faktor ini perlu diteliti untuk mengetahui faktor prioritas yang mempengaruhi investor dalam memilih lokasi pembangunan shopping mall di Kota Surakarta

\section{KAJIAN TEORI}

Definisi shoping mall adalah bangunan besar yang terdiri atas banyak outlettenant dengan luasan minimal 100.000 kaki persegi atau sekitar $9.200 \mathrm{~m} 2$. Shopping mall umumnya berbentuk bangunan tertutup dengan pedestrian yang menghubungkan lokasi-lokasi retail didalamnya dan memiliki anchor sebagai landmark atau daya tarik utamanya (Gilbert, 2003). Shopping mall memiliki berbagai fungsi dan peran. Bagi masyarakat yang sudah tua mereka dapat berolahraga dengan berjalan di Shopping mall dengan suhu yang nyaman dan kondisi yang aman. Sedangkan bagi remaja, shopping mall merupakan sarana untuk berinteraksi dan bermain dengan teman-temannya (Levy \& Weitz, 2009). Terdapat 3 jenis dari pusat perd.agangan yang terencana yaitu pada tingkat Regional, Community, dan Neighborhood (Berman \& Evan, 2001).

Dimensi pemilihan lokasi sangat luas. Pemilihan lokasi melibatkan aspek ekonomi, kondisi geografi, perencanaan kota, dan perilaku konsumen. Dengan pemilihan lokasi yang berbeda dapat menimbulkan dampak yang berbeda pula, baik positif maupun negatif. Terdapat zona atau lokasi yang dapat menarik konsumen lebih dari lokasi lainnya. Zonazona tersebut antara lain zona primer, zona sekunder dan zona pinggir. Hal tersebut ditentukan oleh penggunaan lahan di suatu kota (Gilbert, 2003).

Dalam menentukan faktor pemilihan lokasi digunakan sintesa teori yang diambil dari beberapa ahli/pakar yang menjelaskan mengenai teori lokasi. Teori lokasi yang akan disintesa adalah teori mengenai faktor pemilihan lokasi pusat perdagangan dan faktor pemilihan lokasi shopping mall. Hasil dari kedua sintesa teori tersebut akan menjadi variabel dalam penelitian. Berikut ini merupakan variabel yang diambil dalam penelitian :

Tabel 1. Faktor Pemilihan Lokasi Shopping Mall

\begin{tabular}{|l|l|l|l|l|}
\hline $\begin{array}{c}\text { Sintesa Variabel } \\
\text { Pemilihan Lokasi } \\
\text { Pusat } \\
\text { Perdagangan }\end{array}$ & $\begin{array}{l}\text { Sintesa Variabel } \\
\text { Pemilihan } \\
\text { Lokasi Shopping } \\
\text { mall }\end{array}$ & Variabel Terpilih & Sub Variabel & \multicolumn{1}{|c|}{ Indikator } \\
\hline $\begin{array}{l}\text { Peraturan Zonasi } \\
\text { Daerah setempat }\end{array}$ & $\begin{array}{l}\text { Kesesuaian } \\
\text { Aturan Zonasi }\end{array}$ & $\begin{array}{l}\text { Kesesuaian } \\
\text { Aturan Zonasi }\end{array}$ & - & $\begin{array}{l}\text { Kesesuaian Lokasi } \\
\text { dengan Peraturan } \\
\text { Zonasi }\end{array}$ \\
\hline Lokasi pesaing & - & Lokasi pesaing & $\begin{array}{l}\text { Lokasi dan Jarak } \\
\text { dengan pesaing }\end{array}$ & $\begin{array}{l}\text { Persebaran dan } \\
\text { Jarak/radius lokasi } \\
\text { dengan lokasi pesaing }\end{array}$ \\
\hline $\begin{array}{l}\text { Keterkaitan } \\
\text { Spasial }\end{array}$ & - & Keterkaitan & Generative & $\begin{array}{l}\text { Keterkaitan lokasi } \\
\text { dalam menarik } \\
\text { konsumen } \\
\text { disekitarnya }\end{array}$ \\
\hline
\end{tabular}




\begin{tabular}{|c|c|c|c|c|}
\hline $\begin{array}{c}\text { Sintesa Variabel } \\
\text { Pemilihan Lokasi } \\
\text { Pusat } \\
\text { Perdagangan } \\
\end{array}$ & $\begin{array}{c}\text { Sintesa Variabel } \\
\text { Pemilihan } \\
\text { Lokasi Shopping } \\
\text { mall } \\
\end{array}$ & Variabel Terpilih & Sub Variabel & Indikator \\
\hline & & & Suspicient & $\begin{array}{l}\text { Keterkaitan lokasi } \\
\text { dalam mengambil } \\
\text { keuntungan kegiatan } \\
\text { disekitarnya }\end{array}$ \\
\hline \multirow{3}{*}{ Aksesibilitas } & \multirow{3}{*}{ Aksesibilitas } & \multirow{3}{*}{ Aksesibilitas } & Moda Transportasi & $\begin{array}{l}\text { Kemudahan untuk } \\
\text { dicapai (kendaraan } \\
\text { pribadi dan umum) }\end{array}$ \\
\hline & & & Lalu Lintas & Arus Lalu lintas \\
\hline & & & $\begin{array}{l}\text { Kemudahan } \\
\text { dicapai dari } \\
\text { fasilitas umum }\end{array}$ & $\begin{array}{l}\text { Kemudahan dicapai } \\
\text { dari fasilitas umum }\end{array}$ \\
\hline \multirow{2}{*}{ - } & \multirow{2}{*}{$\begin{array}{l}\text { Ketersediaan } \\
\text { Jaringan } \\
\text { Prasarana }\end{array}$} & \multirow{2}{*}{$\begin{array}{l}\text { Ketersediaan } \\
\text { Jaringan } \\
\text { Prasarana }\end{array}$} & $\begin{array}{l}\text { Ketersediaan } \\
\text { jaringan listrik }\end{array}$ & $\begin{array}{l}\text { Ketersediaan jaringan } \\
\text { listrik }\end{array}$ \\
\hline & & & $\begin{array}{l}\text { Ketersediaan } \\
\text { jaringan drainase }\end{array}$ & $\begin{array}{l}\text { Ketersediaan jaringan } \\
\text { drainase }\end{array}$ \\
\hline - & $\begin{array}{l}\text { Kesesuaian } \\
\text { kondisi geologi } \\
\text { dan hidrologi }\end{array}$ & $\begin{array}{l}\text { Kesesuaian } \\
\text { kondisi geologi } \\
\text { dan hidrologi }\end{array}$ & - & $\begin{array}{l}\text { Kesesuaian kondisi } \\
\text { geologi dan hidrologi }\end{array}$ \\
\hline Konsumen & $\begin{array}{l}\text { Jarak jangkauan } \\
\text { customer }\end{array}$ & $\begin{array}{l}\text { Jarak jangkauan } \\
\text { customer }\end{array}$ & - & $\begin{array}{l}\text { Jarak jangkauan ke } \\
\text { shopping } \begin{array}{l}\text { mall<20 } \\
\text { menit }\end{array} \\
\end{array}$ \\
\hline Biaya & Harga Tanah & Harga Tanah & - & $\begin{array}{l}\text { Keterjangkauan harga } \\
\text { sewa tanah }\end{array}$ \\
\hline
\end{tabular}

Sumber : (Berman \& Evan, 2001), (Gilbert, 2003), (Diana \& Tjiptono, 2003), Ratcliffe (1974), Fandy Tjiptono (Sastrawan, 2015), (Marlina, 2008), (Kwak \& dkk, 2013)

\section{METODE PENELITIAN}

\subsection{PENDEKATAN DAN JENIS PENELITIAN}

Pendekatan penelitian ini dilakukan secara deduktif, sehingga peneliti berangkat dari teori untuk terjun ke lapangan dalam melakukan pencarian data yang kemudian dapat digunakan dalam meneliti faktor apa saja yang mempengaruhi pemilihan lokasi shopping mall. Penelitian yang dilakukan merupakan jenis penilitian kuantitatif. Penelitian ini menggunakan teknik AHP (Analythic Hierarchi Process) yang merupakan teknik analisis kuantitatif. Teknik ini mengubah pendapat-pendapat ahli/stakeholder terkait pemilihan lokasi shopping mall menjadi nilai-nilai kuantitatif. AHP dalam penelitian ini digunakan untuk mengetahui faktor-faktor yang mempengaruhi dan faktor utama dalam penentuan lokasi shopping mall.

\subsection{TEKNIK PENGUMPULAN DATA}

Teknik pengumpulan data yang dilakukan dalam penelitian ini adalah teknik wawancara, kuesioner dan studi literature.Teknik wawancara/kuesioner dilakukan dengan cara menanyakan kebutuhan data penelitian secara langsung kepada narasumber yang dipilih. Sedangkan teknik studi literature menggunakan data sekunder yang didapatkan dari instansi pemerintahan, atau hasil penelitian yang sebelumnya. Pengumpulan data dengan teknik observasi dan wawancara digunakan sebagai pembahasan faktor-faktor yang ada dalam penelitian sedangkan teknik kuesioner digunakan sebagai input data/dasar dalam melakukan analisis Analytic Hierarchy Process (AHP).

\subsection{TEKNIK ANALISIS DATA}

Terdapat dua teknik analisis yang digunakan dalam penelitian ini yaitu analisis AHP (Analithyc Hierarchi Process) dan Analisis Triangulasi. AHP memberikan nilai berupa angka pada pertimbangan subjektif dari narasumber/pakar tentang tingkat kepentingan variabel dan mensintesis berbagai pertimbangan ini untuk menentukan variabel dengan prioritas tertinggi yang akan mempengaruhi hasil pada persoalan yang akan diselesaikan (Saaty, 2008). Hasil dari analisis AHP digunakan untuk menentukan faktor prioritas apa saja yang paling menentukan pemilihan lokasi 
pembangunan shopping mall. Berdasarkan faktor yang ada akan dibuat kuesioner yang akan dibagikan kepada stakeholder antara lain Dinas Perdagangan, Akademisi Ekonomi, Akademisi Tata Ruang, Bappeda, DPMPT (Dinas Penanaman Modal dan Pelayanan Terpadu), Kantor Kecamatan, Kantor Kelurahan, Pihak Pengelola Mall.

Triangulasi merupakan suatu pendekatan analisa data yang mensintesa data dari berbagai sumber. Triangulasi menyatukan informasi dari penelitian kuantitatif (Analisis AHP) dengan kualitatif (Identifikasi Faktor Pemilihan Lokasi Shopping Mall). Analisis Triangulasi digunakan untuk meningkatkan pemahaman peneliti terhadap data dan fakta yang dimilikinya (Sugiyono, 2007). Triangulasi yang dilakukan adalah antara teori ahli/pakar, hasil analisis AHP untuk menentukan prioritas dan identifikasi faktor pemilihan lokasi shopping mall.

\subsection{LOKASI PENELITIAN}

Penelitian dilakukan pada shopping mall yang ada di Kota Surakarta yaitu Solo Grand Mall dan Solo Square yang berada di Jalan Slamet Riyadi serta Solo Paragon yang berada di Jalan Yosodipuro. Batasan waktu penelitian ini adalah pada tahun 2004, 2008 dan 2010. Hal ini didasarkan pada perkembangan persebaran shopping mall pada tahun tersebut. Penelitian ini juga hanya membatasi untuk mengetahui faktor prioritas yang mempengaruhi pemilihan lokasi shopping mall sesuai dengan teori lokasi perdagangan.
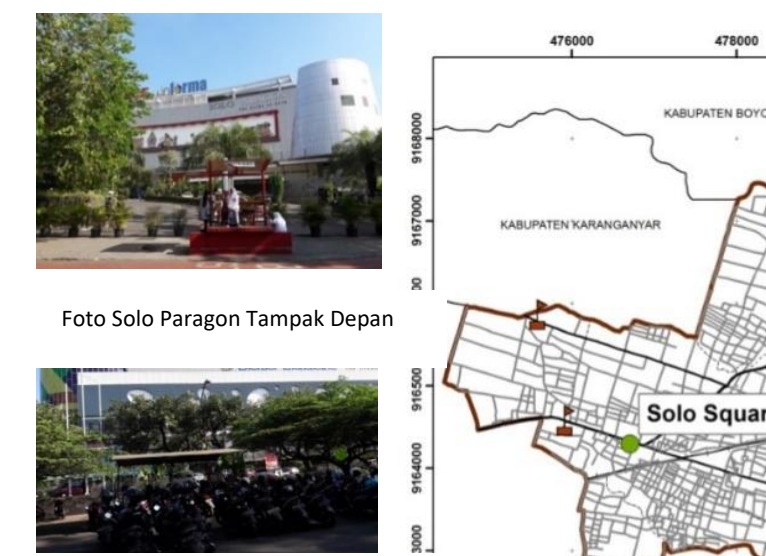

Foto Solo Square Tampak Depan

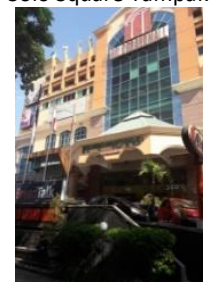

Foto Solo Grand Mall Tampak Depan
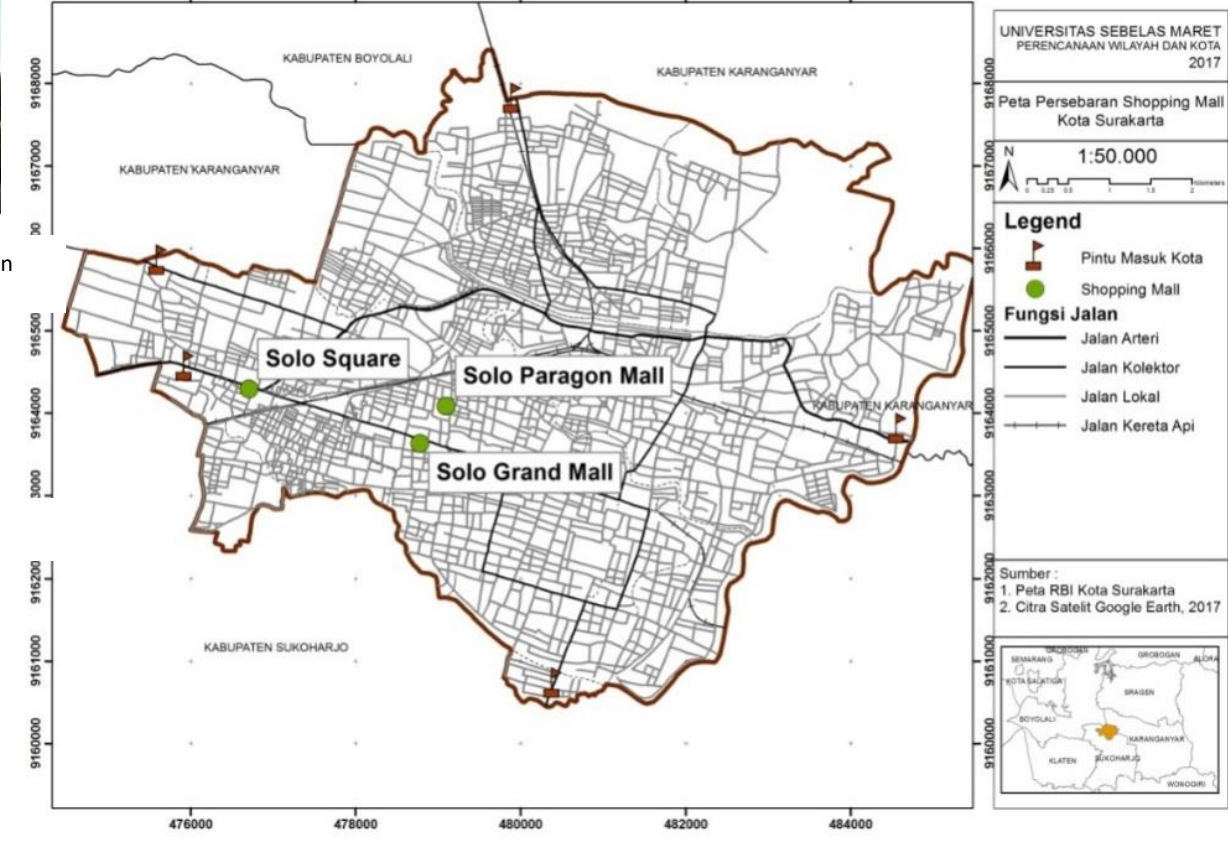

Gambar 1. Peta Persebaran Shopping mall di Kota Surakarta

\section{HASIL DAN PEMBAHASAN}

\subsection{PRIORITAS FAKTOR PEMILIHAN LOKASI SHOPPING MALL}

Setelah melakukan analisis diketahui bahwa faktor pemilihan lokasi setiap shopping mall berbeda-beda. Ketiga shopping mall memiliki penilaian yang beragam terhadap faktor yang ada. Untuk memperjelas perbandingan perbedaan antar shopping mall, berikut ini merupakan diagram batang yang menunjukan perbandingan faktor pemilihan lokasi shopping mall di Kota Surakarta : 


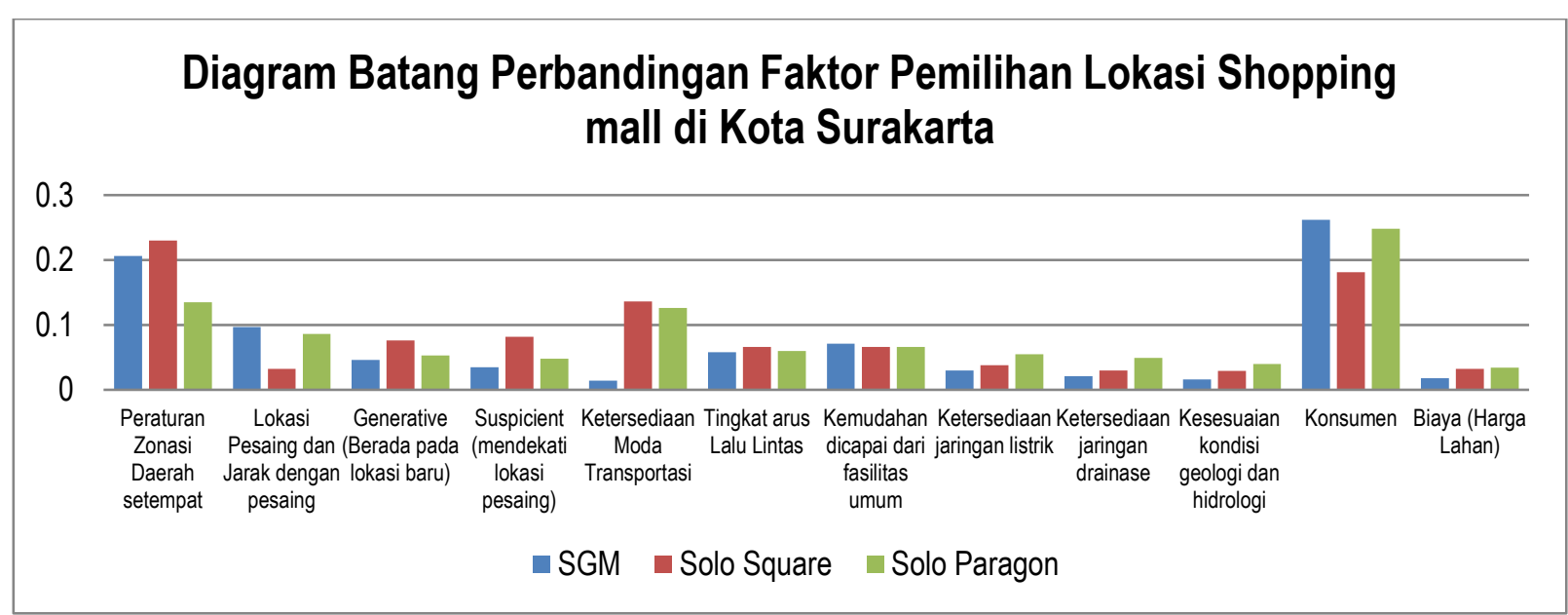

Sumber : Satria, Darryl Hall Stevanda Dwi, dkk., 2017

Gambar 2. Diagram Batang Perbandingan Faktor Pemilihan Lokasi Shopping mall di Kota Surakatra

Setelah mengetahui hasil tingkat prioritas dari setiap shopping mall, peneliti melakukan analisis terhadap keseluruhan ahli yang telah dipilih dalam mengisi kuesioner mengenai faktor pemilihan lokasi shopping mall di Kota Surakarta dengan objek Solo Grand Mall, Solo Square, dan Solo Paragon. Berdasarkan hasil analisis didapatkan bahwa faktor yang menjadi prioritas bagi investor yaitu faktor peraturan zonasi daerah, konsumen dan ketersediaan moda transportasi. Peraturan zonasi menjadi faktor yang paling utama karena jika kawasan/zona yang akan dibangun shopping mall tidak sesuai dengan aturan pemanfaatan ruang kawasan tersebut maka pemerintah daerah setempat tidak akan memberikan ijin dan pembangunan tidak akan berjalan. Investor harus memperhatikan lokasi yang paling strategis dan sesuai dengan aturan pemanfaatan ruang. Faktor konsumen menjadi faktor yang diprioritaskan. Konsumen merupakan penentu berhasil atau tidaknya shopping mall tersebut. Dengan mendapatkan konsumen yang lebih banyak, investor akan mendapat keuntungan yang besar pula. Ketersediaan moda transportasi seperti adanya trayek bus dan angkutan membuat shopping mall lebih mudah dicapai. Moda transportasi umum dapat menghubungkan fasilitasfasilitas umum lainnya seperti fasilitas pendidikan, fasilitas kesehatan dan perkantoran sehingga memilih lokasi yang dilewati oleh transportasi umum akan lebih menguntungkan bagi investor.

Combined instance - Synthesis with respect to:

Faktor Pemilihan Lokasi Shopping Mall

Overall Inconsistency $=, 08$

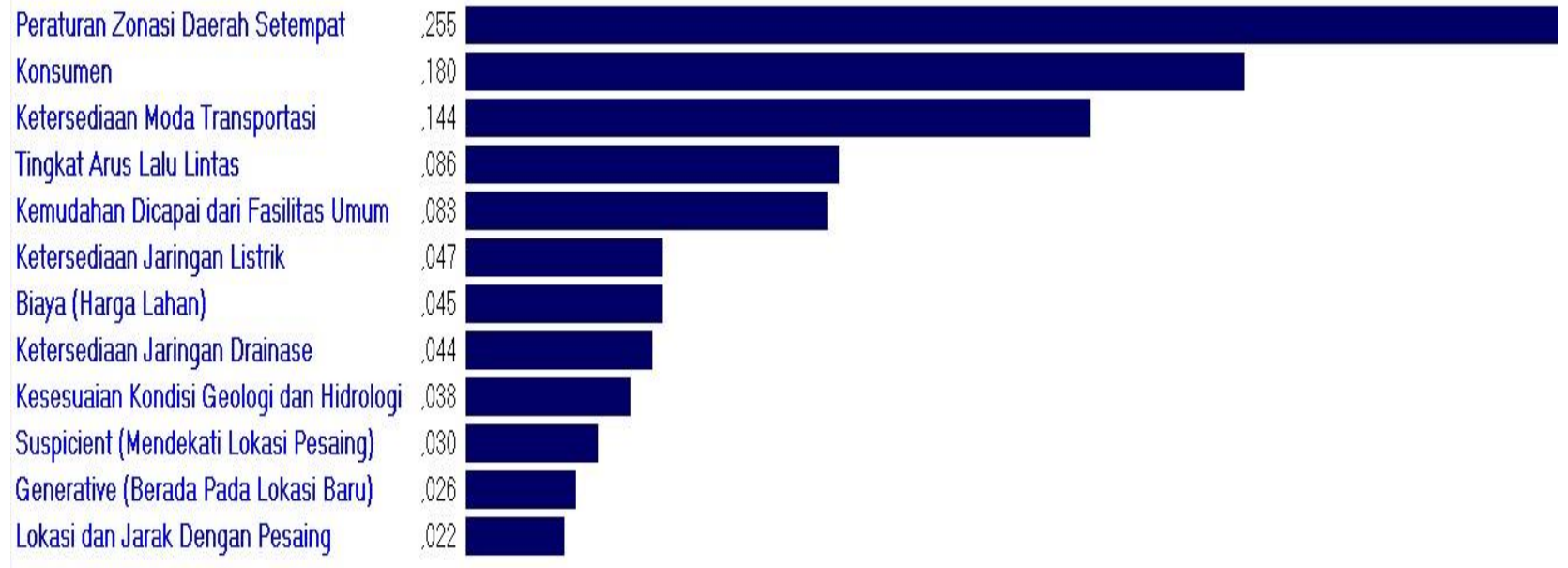

Sumber : Satria, Darryl Hall Stevanda Dwi, dkk., 2017

Gambar 3. Grafik Prioritas Faktor Pemilihan Lokasi Shopping Mall di Kota Surakarta 
Selanjutnya dalam penelitian ini untuk meningkatkan pemahaman mengenai topik dan pembahasan. Analisis triangulasi yang digunakan adalah triangulasi sumber untuk memperjelas hubungan antara teori ahli, hasil akhir prioritas AHP dan identifikasi faktor pemilihan lokasi shopping mall.

\subsection{PEMBAHASAN}

\section{Peraturan Zonasi Daerah Setempat}

Peraturan zonasi merupakan faktor yang paling penting dan diprioritaskan dalam pemilihan lokasi shopping mall di Kota Surakarta. Peraturan zonasi yang belaku pada saat tahun berdirinya ketiga shopping mall tersebut adalah Rencana Detail Tata Ruang Kota Surakarta bagian selatan tahun 1996. Sesuai dengan pendapat dari Fandy Tjiptono, ketentuan pemerintah harus dipatuhi agar tidak menyalahi arahan pemanfaatan ruang yang telah diatur oleh pemerintah setempat (Sastrawan, 2015).

Dalam menentukan lokasi berdirinya suatu shopping mall, investor akan mempertimbangkan peraturan zonasi yang berlaku pada daerah tersebut terlebih dahulu. Untuk mendapatkan ijin pembangunan, lokasi yang dipilih oleh investor harus sesuai dengan peraturan zonasi yang ada. Peraturan zonasi menjadi faktor yang absolut dalam pemilihan lokasi shopping mall. Jika lokasi yang dipilih tidak sesuai dengan peraturan zonasi maka shopping mall tersebut tidak akan dapat dibangun dan investor tanpa perlu mempertimbangkan faktor lainnya lagi harus memindahkan lokasi shopping mall tersebut.

\section{Konsumen}

Konsumen merupakan hal yang terpenting bagi keberadaan sebuah shopping mall (Schiffman \& Kanuk, 2004). Terdapat dua hal yang harus diperhatikan yaitu segmentasi pasar dan jangkauan pelayanan. Keberhasilan dalam menetapkan segmen pasar berarti akan berhasil menjadikan konsumen potensial menjadi konsumen yang sesungguhnya.

Berdasarkan kondisi yang ada di Kota Surakarta, setiap shopping mall harus memiliki strategi yang tepat dalam menentukan pangsa pasar dan juga lokasi yang paling optimal untuk melayani konsumen tersebut. Setiap shopping mall memiliki kriteria yang berbeda dalam memilih konsumen misalnya masyarakat yang berada ditengah kota, masyarakat sekitar, masyarakat berpenghasilan tinggi atau bahkan masyarakat berpenghasilan menengah kebawah.

\section{Ketersediaan Moda Transportasi}

Shopping mall di Kota Surakarta memperhatikan dan memilih lokasi dengan akses transportasi umum yang paling baik. Pada tahun 2004 hingga 2010, Kota Surakarta dilayani oleh angkutan bus umum dan angkutan umum. Lokasi yang dilalui atau mudah dijangkau sarana transportasi umum akan lebih sering dikunjungi oleh konsumen (Diana \& Tjiptono, 2003) (Berman \& Evan, 2001) (Sastrawan, 2015). Oleh karena itu, transportasi umum bisa menjadi hal yang penting dan faktor yang tidak bisa diabaikan dalam pemilihan lokasi sebuah shopping mall. Lokasi yang dilalui oleh semakin banyak jalur transportasi umum akan membuat lokasi tersebut semakin diminati oleh konsumen sebagai salah satu pilihan lokasi yang strategis.

\section{4. $\quad$ Tingkat Arus Lalu Lintas}

Shopping mall di Kota Surakarta lebih memilih lokasi yang tidak terlalu padat agar konsumennya mudah untuk mengunjungi shopping mall tersebut. Berdasarkan analisis sebelumnya, didapatkan bahwa ketiga shopping mall memilih lokasi dengan arus yang stabil dan dapat dikendalikan. Tingkat arus lalu lintas merupakan salah satu faktor terpenting (Berman \& Evan, 2001) (Diana \& Tjiptono, 2003). Hal ini dikarenakan konsumen cenderung enggan untuk mengunjungi shopping mall tersebut jika arusnya padat dan sulit untuk dijangkau. Shopping mall di Kota Surakarta memilih jalan utama namun dengan arus yang stabil dengan begitu konsumen akan lebih tertarik untuk mengunjunginya.

\section{Kemudahan Dicapai dari Fasilitas Umum}

Shopping mall di Kota Surakarta melihat fasilitas umum disekitarnya sebagai kegiatan yang akan mendatangkan konsumen paling banyak. Fasilitas umum tersebut antara lain fasilitas kesehatan, fasilitas pendidikan, fasilitas perkantoran dan fasilitas umum lainnya. Jarak yang diperhitungkan adalah $\pm 5-10$ menit dalam jalan. Dalam hal ini Kemudahan suatu tempat untuk dijangkau merupakan faktor dalam aksebilitas yang terpenting (Ratcliff, 1974). Namun 
dikota Surakarta melihat kemudahan dicapai dari fasilitas umum merupakan faktor dari variabel aksesibilitas yang terendah.

\section{Ketersediaan Jaringan Listrik}

Jaringan listrik merupakan hal yang sangat penting dalam operasionalisasi sebuah shopping mall. Hal ini didukung oleh teori dari Marlina mengenai kawasan komersial bahwa pembangunan shopping mall akan memperhatikan aspek ketersediaan jaringan utilitas yang memadai untuk menunjang fungsi dan kinerja dari shopping mall tersebut. Dalam teori tersebut prasarana utama yang perlukan adalah jaringan listrik terlebih dahulu.

Oleh karena itu lokasi yang mudah teraliri listrik menjadi lokasi yang sangat diprioritaskan. Di Kota Surakarta sendiri seluruh kawasannya sudah teraliri listrik dengan baik, sehingga shopping mall tidak terlalu sulit dalam memilih lokasi yang sesuai. Lokasi shopping mall di Kota Surakarta berada pada jalan utama sehingga lebih mudah mendapatkan aliran listrik. Jika terdapat gangguan listrikpun akan lebih mudah mengatasinya karena jalurnya yang mudah dicapai.

\section{Biaya (Harga Lahan)}

Hal yang sangat diwaspadai oleh investor adalah mengenai harga lahan yang akan ditempati. Investor akan memperhitungkan agar harga lahan tidak terlalu mahal dan investor tersebut lebih cepat untuk balik modal dan mendapatkan keuntungannya. Tetapi jika faktor-faktor sebelumnya telah terpenuhi dan lokasi tersebut adalah lokasi yang paling strategis, para investor akan menanamkan modalnya pada lokasi tersebut. Seperti halnya yang terjadi di Surakarta, harga lahan yang ditempati oleh ketiga shopping mall adalah harga lahan yang tertinggi pada tahun tersebut yaitu harga lahannya bernilai sekitar 10.000.000 hingga 20.000.000. Harga lahan tersebut tergolong mahal dan terdapat pada persil lahan pertama dipinggir jalan utama. Menurut R.V.Ratcliff, konsep zona penggunaan lahan kota merlihat berdasarkan variabel kemampuan membayar sewa lahan (land value) dan jarak dari pusat kota. Meskipun lahan tersebut tergolong mahal tetapi investor-investor tersebut tetap membangun pada lokasi tersebut karena letaknya yang strategis dan sesuai dengan pasaran mall tersebut.

\section{Ketersediaan Jaringan Drainase}

Seperti halnya jaringan listrik, berpendapat bahwa sebuah shopping mall tidak akan mengabaikan jaringan drainase sebagai fungsi kinerja shopping mall tersebut (Marlina, 2008). Shopping mall perlu diperhatikan dari jaringan drainase adalah mengenai ketersediaan, kondisi dan jenis dari drainase (Marlina, 2008). Jaringan drainase diperlukan sebagai salah satu dari operasionalisasi shopping mall. Shopping mall di Kota Surakarta lebih memilih berada pada jaringan drainase dengan jenis drainase tertutup karena dengan kondisinya tertutup membuat jaringan tersebut tidak butuh banyak perawatan. Jaringan drainase tertutup cenderung lebih lama mengalami sedimentasi karena terhindar dari sampah perkotaan. Sampah-sampah tersebutlah yang menyebabkan terjadinya penyumbatan pada jaringan drainase sehingga ketika musim hujan akan terjadi genangan akibat meluapnya air pada jaringan drainase tersebut. Namun bagi shopping mall di Kota Surakarta jaringan drainase bukanlah hal yang perlu dikhawatirkan. Secara umum, kondisi jaringan drainase di Kota Surakarta merupakan jaringan drainase tertutup sehingga jarang terjadi genangan atau banjir ketika musim hujan.

\section{Kesesuaian Kondisi Geologi dan Hidrologi}

Investor harus melihat kemampuan lahan dari lokasi yang dipilih untuk menentukan ketahanan lahan yang akan dibangun (Marlina, 2008). Kegiatan shopping mall harus melihat kemampuan lahan lokasi tersebut agar tidak terjadi kerusakan lahan atau robohnya bangunan. Geologi dan Hidrologi dilihat dari tingkat kemampuan lahan pada lokasi tersebut. Berdasarkan kondisi kemampuan lahan yang ada pada blok yang dipilih oleh shopping mall memiliki prosentase dibangun $5 \%$ sehingga tinggi maksimal bangunan tersebut adalah 4 lantai atau sekitar 9-20 meter. Eksisting bangunan shopping mall di Kota Surakarta memiliki tinggi bangunan 5 lantai dan 1 lantai basement.

Kondisi yang ada di Kota Surakarta berbanding terbalik dengan pendapat Marlina, dengan kecanggihan teknologi dan berbagai rekayasa lahan yang ada kondisi geologi dan hidrologi bukan merupakan sebuah halangan. Untuk membangun shopping mall tersebut pihak investor melakukan beberapa rekayasa lahan sehingga mampu menampung beban bangunan shopping mall. Berdasarkan kondisi tersebut dapat simpulkan bahwa untuk pemilihan lokasi shopping mall kondisi kemampuan lahan tidak terlalu diperhatikan karena sudah terdapat beberapa rekayasa-rekayasa lahan yang dapat diterapkan. 


\section{Suspicient}

Keterkaitan spasial kurang penting untuk diperhitungkan dalam menentukan lokasi shopping mall (Ratcliff, 1974). Pernyataan ini didukung oleh Diana yang memperjelas perbedaan antara keterkaitan suspicient dan generative. Suspicient merupakan keterkaitan lokasi dalam mengambil keuntungan kegiatan disekitarnya. Setelah menentukan lokasi yang paling tepat untuk pembangunannya, shopping mall melihat kegiatan apa saja yang ada disekitar lokasi tersebut. Dengan mengetahui kegiatannya yang ada disekitarnya shopping mall tersebut dapat menentukan strategi yang tepat untuk menarik konsumen dari kegiatan-kegiatan tersebut. Meskipun tidak terlalu signifikan namun faktor ini bagi shopping mall di Kota Surakarta, memaksimalkan keuntungan yang bisa didapatkan dengan memanfaatkan kegiatan disekitar area pembangunan shopping mall tersebut.

\section{Generative}

Seperti halnya keterkaitan spasial suspicient, keterkaitan spasial generative juga diperhitungan dalam pemilihan lokasi shopping mall. Keterkaitan lokasi dalam menarik konsumen disekitarnya. Berbeda dengan suspicient, dalam generative menarik konsumen berdasarkan jumlah penduduk yang dapat dilayani pada suatu lokasi. Solo Grand Mall yang berada di tengah Kota Surakarta memiliki keuntungan untuk menarik konsumen yang berada di dalam Kota Surakarta. Solo Square yang berada dipinggir kota lebih mudah untuk menarik konsumen dari kawasan sekitar Kota Surakarta karena lebih mudah dijangkau. Analisa ambang batas jumlah penduduk menjadi salah satu analisa yang diperhatikan oleh investor dalam menentukan lokasi shopping mall. Namun faktor ini mejadi faktor akhir untuk dipertimbangkan oleh shopping mall di Kota Surakarta. Shopping mall di Kota Surakarta tidak terlalu khawatir dalam hal menarik konsumen karena setiap shopping mall memiliki caranya masing-masing.

\section{Lokasi dan Jarak dengan Pesaing}

Lokasi pesaing merupakan faktor yang terakhir dalam pertimbangan investor untuk memilih lokasinya. Hal ini berbeda dengan yang dikatakan oleh Gilber dan Fandi Tjiptono. Mereka mengatakan bahwa lokasi dan jarak dengan pesaing adalah faktor yang akan paling diutamakan dalam pemilihan lokasi shopping mall (Gilbert, 2003) (Tjiptono dalam Sastrawan, 2015). Namun kenyataannya di Kota Surakarta lokasi dan jarak dengan pesaing merupakan faktor yang paling akhir untuk pertimbangan investor dalam memilih lokasinya. Lokasi pesaing dilihat setelah shopping mall tersebut sudah mempertimbangkan berbagai faktor-faktor yang sebelumnya. Seperti yang terjadi di Kota Surakarta terdapat dua shopping mall yang saling berdekatan dengan jarak $\pm 1 \mathrm{~km}$. Jarak tersebut merupakan jarak yang dekat untuk pengembangan sebuah shopping mall. Tetapi Solo Paragon sebagai shopping mall yang berdiri terakhir tidak terlalu mempermasalahkan hal tersebut. Solo Paragon mempertimbangkan faktor kesesuaian zonasi, konsumen dan ketersediaan moda transportasi terlebih dahulu. Ketika ketiga faktor tersebut sudah terpenuhi, lokasi pesaing baru akan dipertimbangkanasi dan jarak dengan pesaing merupakan faktor yang paling akhir untuk pertimbangan investor dalam memilih lokasinya.

\section{KESIMPULAN}

Memilih lokasi yang tepat merupakan kunci dari keberhasilan berkembangnya sebuah shopping mall. Investor harus memahami kondisi dari faktor-faktor ada pada daerah tersebut. Shopping mall merupakan salah satu jenis investasi penanaman modal dengan jangka waktu yang lama, sehingga jika investor memilih lokasi yang salah akan berakibat negatif dimasa yang akan datang. Isu utama di Kota Surakarta ada dengan banyaknya investor yang menanamkan modalnya dibidang perdagangan yaitu shopping mall dan memilih lokasi di bagian selatan Kota Surakarta. Awalnya berkembangnya shopping mall di Surakarta adalah pada tahun 2004 dimana Solo Grand Mall mulai beroperasi.

Berdasarkan ketiga objek shopping mall yang telah berdiri di Kota Surakarta dan pendapat beberapa ahli terkait, telah didapatkan hasil prioritas dari faktor apa saja yang digunakan oleh investor dalam memilih lokasi yang paling strategis untuk shopping mall mereka. Secara umum, hasil prioritas pemilihan lokasi shopping mall di Kota Surakarta yaitu peraturan zonasi daerah setempat, konsumen dan ketersediaan moda transportasi, tingkat arus lalu lintas, kemudahan dicapai dari fasilitas umum, ketersediaan jaringan listrik, biaya (harga lahan), keterseiaan jaringan drainase, kesesuaian kondisi geologi dan hidrologi, suspicient, generative, dan yang terakhir adalah lokasi dan jarak dengan pesaing. 


\section{DAFTAR PUSTAKA}

Berman, B., \& Evan, J. (2001). Retail Management. United State of America: Pearson Education.

Diana, A., \& Tjiptono, F. (2003). Total Quality Management. Yogyakart: Penerbit Andy.

Gilbert, D. (2003). Retail Marketing Management. England: Pearson Education.

Kwak, Y., \& dkk. (2013). The Development of Location Decision Making Support System for Chinese Shopping Mall from Developers' Perspective. International Journal of Smart Home, 7(5), 315-326.

Levy, M., \& Weitz, B. A. (2009). Retailing Management. New York: McGraw-Hill.

Marlina. (2008). Panduang Perancangan Bangunan Komersial. Yogyakarta: Andi Offset.

Ratcliff, J. (1974). Introduction to Town and Country Planning. London: Hutchinson.

Saaty, T.L. (2008) Decision Making with the Analytic Hierarchy Process,. Int. J. Services Sciences, Vol. 1, No. 1, 83-98

Sastrawan, I. W. (2015). Analisis Faktor-Faktor Yang Mempengaruhi Pemilihan Lokasi Usaha Pedagang Kaki Lima di Pantai Penimbangan Kecamatan Buleleng, Kabupaten Buleleng. Jurnal Universitas Pendidikan Ganesha, 5.

Schiffman, \& Kanuk. (2004). Perilaku Konsumen. Jakarta: Prentice Hall.

Sugiyono. 2007. Metode Penelitian Kuantitatif Kualitatif dan R\&D. Bandung: Alfabeta.

Perwali No 12 Tahun 2014 tentang Rencana Umum Penanaman Modal di Kota Surakarta

Rencana Detail Tata Ruang Kota Surakarta bagian selatan tahun 1996 